\title{
THE QUALITY OF LANDRACE PIG SPERMATOZOA DURING THE COLD STORAGE PROCESS USING BTS AND CEP-3 DILUENTS ADDED 10\% EGG YOLK AT TEMPERATURES OF $2-5^{\circ} \mathrm{C}$
}

\author{
Feka Wolfhardus Vinansius, Postgraduate Student \\ Isnaini Nurul, Susilawati Trinil, Lecturers \\ Faculty of Animal Husbandry, University of Brawijaya, Malang, Indonesia \\ *E-mail: wolfhardusfeka@gmail.com
}

\begin{abstract}
In East Nusa Tenggara many Landrace pigs are used to fullfil the protein needs of the community and Artificial Insemination has been used to improve the genetic quality of pigs. The objective of this study was to find out the period of cold storage on the quality of the Landrace pig spermatozoa using BTS and CEP-3 diluents and added 10\% egg yolk. This research was conducted at the Laboratory of the Faculty of Agriculture of Timor University using Landrace pig spermatozoa. The research method is a laboratory experiment using 2 treatments with 10 replications, namely T1 (BTS) and T2 (CEP-3 $+10 \%$ egg yolk) which stored at refrigerator temperature of $2-5^{\circ} \mathrm{C}$. The variables observed were individual motility and membrane integrity of spermatozoa. Data were analyzed using Randomized Block Design (RBD) Motility percentage using Pearson's ChiSquare with an expected value of 40 million motile sperm $/ \mathrm{ml}$. The results showed that the percentage of individual motility at storage period of the $3^{\text {rd }}$ hour type of diluent had no significant effect $(P>0.05)$ whereas at the storage time/period of the $6^{\text {th }}, 9^{\text {th }}, 24^{\text {th }}, 48^{\text {th }}$ and $72^{\text {nd }}$ hours percentage of individual motility T1 with the value of $66.5 \%, 61.5 \%, 52.5 \%, 42.5 \%, 32 \%$ significantly different $(\mathrm{P}<0.05)$ towards and T2 by $63 \%, 57.5 \%, 42.5 \%, 31.5 \%, 17 \%$. The percentage of membrane integrity in this study shows that the storage period of the $3^{\text {rd }}$ hours the diluent type has no effect (P> $0.05)$ on the membrane integrity of Landrace pig spermatozoa. Menwhile at $6^{\text {th }}, 9^{\text {th }}, 24^{\text {th }}, 48^{\text {th }}$, and $72^{\text {nd }}$ hours showed that the treatment of $\mathrm{T} 1$ with a value of $77.68 \%, 73.59 \%, 64.61 \%$, $52.71 \%$, and $42.18 \%$ respectively gave a significant effect $(P<0.05)$ on $T 2$ with a value of $75.86 \%, 67.73 \%, 57.95 \%, 47.09 \%$ and $33.71 \%$ respectively. The conclusion of this study namely diluent that has a higher advantage in maintaining the quality of spermatozoa of Landrace pigs at a temperature of $2-5^{\circ} \mathrm{C}$ is BTS diluent which has the highest percentage of motility compared to CEP-3 diluent $+10 \%$ egg yolk. The results showed that BTS diluent can be stored for 48 hours while CEP-3 diluent $+10 \%$ egg yolk can be stored for 24 hours with a minimum percentage of spermatozoa motility of $40 \%$.
\end{abstract}

\section{KEY WORDS}

Spermatozoa, Landrace pigs, individual motility, membrane integrity, Beltsville thawing solution, CEP-3.

Pig is one of the meat producing commodities that has great potential to be developed, this is because pigs have favorable properties and capabilities among others rapid growth, high litter size and good ration efficiency (75-80\%) as well as a high carcass percentage (65$80 \%$ ) with the cutbacks conducted at the age of 12 months (Aberle et al. 2001).

Increased productivity of livestock in Indonesia has been carried out by applying livestock reproduction biotechnology through Artificial Insemination (Al) techniques to improve the genetic quality (Susilawati, 2013). The use of frozen Semen for certain areas experiencing problems of the limited liquid nitrogen. One alternative to overcome this obstacle is by Al using liquid Semen. Liquid Semen has many advantages such as easier manufacturing techniques and cheaper costs (Zaenuri et al., 2014). The making of liquid Semen also requires diluents that have easy and inexpensive conditions and are able to provide nutrients as an energy source for spermatozoa (Susilawati, 2011). 
BTS diluent is currently the most widely used by farmers who conduct Al because of its affordable price and good results. The results of the study of Kadirvel et al. (2005) showed BTS can be used as a diluent of Semen pig with storability for 4 days in a temperature of $17^{0} \mathrm{C}$, with motility at the $4^{\text {th }}$ day observation reaching $64.43 \%$. Another study by Kommisrud et al. (2002) stated that using BTS diluent for 6 hours of storage at a temperature of $16-18^{\circ}$ C showed a percentage of spermatozoa motility $79.8 \%$.

Caudal Epididymis Plasma (CEP) is a type of diluent that is widely used in liquid semen. The ion composition and osmolarity contained in the CEP are almost the same as the composition of the seminal fluid in cauda epididymis, so that it can support the life of the spermatozoa. Indriani, Susilawati, Wahyuningsih (2013) stated that CEP-2 diluents with a mixture of $10 \%$ egg yolk were able to maintain the quality of spermatozoa to remain good, minimize damage to cell membranes and maintain motility of spermatozoa. CEP-3 diluent is a modified diluent from CEP-2 which has been carried out by Sholikah et al (2016) with the use of $0,4 \%$ albumin to replace BSA and the addition of $10 \%$ egg yolk. The use of $0,4 \%$ egg white was able to replace BSA in CEP-2 diluent for liquid Semen which stored at $3-5^{\circ} \mathrm{C}$ reviewed from the percentage of motility, viability and abnormalities of spermatozoa.

Based on the background and thoughts mentioned above, then this study was conducted to test individual motility and total of liquid Semen motile spermatozoa of the pig using BTS and CEP-3 diluents $+10 \%$ egg yolk that stored at temperatures of $2-5^{\circ} \mathrm{C}$ to find out the storage period of Landarce pig liquid Semen and can be used in the process of artificial insemination (Al).

\section{MATERIALS AND METHODS OF RESEARCH}

This research was conducted at the Laboratory of the Faculty of Agriculture, University of Timor, Subdistrict of Kota Kefamenanu, Regency of Timor Tengah Utara, East Nusa Tenggara Province from September to October 2018. The material used in this study is Semen from storage result of 3 (three) Landrace pig studs with an age of 3 years and $270 \mathrm{~kg}$ pig weight using dummy. Semen used in this study had mass motility criteria ++ and individual motility $\geq 70 \%$. Egg yolks derived from the egg of fresh laying hens (egg age less than 3 days).

Semen from the storage results is tested macroscopically and microscopically. Macroscopic tests include volume, color, consistency and $\mathrm{pH}$. Microscopic tests include concentration, motility, viability, abnormalities and membrane integrity of the spermatozoa.

This research method is a laboratory experiment with experimental design in this study using the Randomized Block Design (RBD) method with 2 treatments with 10 replications as a group. The treatment conducted is BTS and CEP-3 diluents $+10 \%$ egg yolk stored in a refrigerator with a temperature of $2-5^{\circ} \mathrm{C}$. Observations were made after storing the $3 \mathrm{rd}, 6 \mathrm{th}$, 9th, 24th, 48th and 72nd hours.

The basic diluent material used is a diluent ready to use BTS $®$. The making of diluents begins with weighing $5 \mathrm{~g}$ of BTS powder and inserted into an Erlenmeyer glass, add aquabides $100 \mathrm{ml}$ then homogenize the mixture for several minutes until homogeneous, and stored at water bath at the temperature of $37^{\circ} \mathrm{C}$ used after the Semen has been stored.

Mixing of materials as follows: $\mathrm{NaCl} 0,887 \mathrm{~g}, \mathrm{KCl} 0,522 \mathrm{~g}, \mathrm{CaCl} 2(\mathrm{H} 2 \mathrm{O}) 2$ 0,441 g, $\mathrm{MgCl} 2(\mathrm{H} 2 \mathrm{O}) 6$ 0,813 g, NaHCO3 0,999 g, NaH2PO4 1,104 g, KH2PO4 2,722 g, Fructose 9,91 g, Sorbitol $1 \mathrm{~g}$, Tris 16,196 g, gentamicin-S 0,05 g/L, and added citric acid 8,198 $\mathrm{g}$ and $1.000 \mathrm{ml}$ aquabidest. The finished diluent is placed in a test tube until it reaches $\mathrm{pH} 6,6.10 \%$ egg yolk, $0,4 \%$ albumin added after the Semen is ready to be diluted.

The variables observed in this study were the quality of sperm from diluted landrace pig Semen, including:

Individual motility. Assessment of individual motility was observed by taking one drop of Semen using an ose placed on top of a glass object and closed using a glass cover then examined under a light microscope with a magnification of 400 times. Calculation is done by determining the percentage of spermatozoa that moves progressively forward in one field of view (Susilawati, 2011). 
Spermatozoa Membrane Integrity. Testing of spermatozoa cell membrane integrity to see membrane status using the Hypo Osmotic Swelling (HOS) test according to Susilawati method (2011). The test was carried out by adding $0,1 \mathrm{ml}$ of the Semen sample into $1 \mathrm{ml}$ of the hypoosmotic solution $150 \mathrm{mOsmol}$ in an eppendorf tube then incubated at $37^{\circ} \mathrm{C}$ for 30 minutes. After incubation, one drop is taken and placed on a glass object and then covered with a glass cover and observed using a 400 times magnification microscope. Observations were made on typical changes that occur, namely the presence of a circular swelling or tail end that identifies the integrity of the membrane plasma (Indriani et al., 2013). Calculations were performed on 200 observed spermatozoa.

Data from the results of the study were analyzed using variance analysis in Randomized Block Design (RBD) which grouped by replication (shelter/storage time). If there is a significant difference, continue with the Multiple Range Test (Duncan). Individual motility was tested by Pearson's Chi Square with an expected value of $40 \%$ to ensure that Semen was still suitable to be used for Al purposes according to Indonesian National Standard/SNI.

\section{RESULTS AND DISCUSSION}

The average value of Semen evaluation from this study can be seen in Table 1.

Table 1 - Semen Examination Results

\begin{tabular}{|c|c|}
\hline Color & Yellowish white \\
\hline Smell & Typical \\
\hline Consistency & Liquid \\
\hline $\mathrm{pH}$ & $7.0 \pm 0.0$ \\
\hline Volume $(\mathrm{ml})$ & $221 \pm 25.14$ \\
\hline Concentration $\left(10^{6} / \mathrm{ml}\right)$ & $188 \pm 53.01$ \\
\hline Mass motility & ++ \\
\hline Individual Motility $(\%)$ & $74 \pm 2.10$ \\
\hline
\end{tabular}

In Table 1 shows that the results of the macroscopic examination of the average value of Landrace pig Semen volume produced by the study are $221 \pm 25.14 \mathrm{ml}$ per ejaculate in the range of $190-260 \mathrm{ml}$. The volume of Landrace pig Semen produced in the study shows the normal range. In line with Sumardani et al., (2008) stated that the volume of fresh Semen of pigs ranges from 150-250 ml per ejaculation. Pig Semen volume measurement is done by looking at the scale on the tubes used.

Observation of the color and smell of fresh pig Semen is carried out during the shelter/storage. The color and smell of the Landrace pig Semen from the result of the study showed that the fresh Semen of Landrace pig was yellowish white (creamy) and has typical smell. The color and smell of fresh Semen produced shows that the condition of Semen is included in the good category, not contaminated with blood, pus, urine or other contaminating substances. The degree of acidity or $\mathrm{pH}$ of Landrace pig Semen during the study of ten constant shelters/storage, ie an average of $7.0 \pm 0.0$ with liquid consistency. Fresh Semen has a pH of 7 can be said to be normal because this result is consistent with what has been said by Bearden et al (2004), Garner and Hafez (2008) that the average pH of normal Semen is 6.8-7.8.

Observation data in the study obtained the value of mass motility (mass movement) is ++ . Mass motility of spermatozoa categorized into three groups namely the mass movement of spermatozoa resemble the thick clouds and fast moving $(+++)$,spermatozoa mass movements resemble thick clouds and move rather slowly $(++)$ and the movement of the spermatozoa resembles thin clouds and moves slowly (+) (Richard et al., 2016). The average value of mass motility from the results of the study shows the level of activity of the movement of the spermatozoa is classified as moderate.

The microscopic test results on the quality of Landrace Pig liquid semen obtained by individual motility averages $74 \pm 2.10 \%$. The individual motility presentations of the study results were classified as normal spermatozoa motility namely $50-80 \%$ (Garner and Hafez 2008). Factors that can affect the motility of spermatozoa in pigs are age, genetics, cattle 
breed, environment and feed. The percentage of motility in this study is relatively high, this is meant so that the spermatozoa used are more able to survive during the storage process. The average concentration of fresh spermatozoa obtained was $188 \pm 53.01$ (106/ ml). This result is the same as Sumardani (2008): Johnson et al. (2000); Gadea (2003); Robert (2006) namely $191,65 \pm 71,1(106 / \mathrm{ml})$.

Table 2 - The percentage of Landrace pigs spermatozoa motility at the temperature of $2-5^{\circ} \mathrm{C}$

\begin{tabular}{ccc}
\hline Hour & Treatment & Individual Motility (\%) \\
\hline \multirow{2}{*}{3} & T1 & $69 \pm 2.11$ \\
& T2 & $69 \pm 2.11$ \\
\hline \multirow{2}{*}{6} & T1 & $66.5 \pm 3.37^{\mathrm{b}}$ \\
& T2 & $63 \pm 2.58^{\mathrm{a}}$ \\
\hline \multirow{2}{*}{9} & $\mathrm{~T} 1$ & $61.5 \pm 3.37^{\mathrm{b}}$ \\
\multirow{2}{*}{24} & T2 & $57.5 \pm 2.64^{\mathrm{a}}$ \\
\hline \multirow{2}{*}{48} & $\mathrm{~T} 1$ & $52.5 \pm 2.64^{\mathrm{b}}$ \\
& T2 & $42.5 \pm 2.64^{\mathrm{a}}$ \\
\hline \multirow{2}{*}{72} & $\mathrm{~T} 1$ & $42.5 \pm 2.64^{\mathrm{b}}$ \\
& T2 & $31.5 \pm 2.42^{\mathrm{a}}$ \\
\hline
\end{tabular}

Note: 1. T1 (BTS) and T2 (CEP-3 + KT 10\%); 2. Different notations in the same column show significantly different $(P<0,05)$.

The results of the variance analysis showed that the storage period of the 3rd hours of the diluent type had no significant effect $(P>0.05)$ on spermatozoa motility of Landrace pigs. This is presumably because at the 3rd hour the diluent still provides the same protection towards the motility of the spermatozoa. whereas at the storage time/period of the $6^{\text {th }}, 9^{\text {th }}$, $24^{\text {th }}, 48^{\text {th }}$ and $72^{\text {nd }}$ hours the percentage of individual motility T1 with the value of $66.5 \%$, $61.5 \%, 52.5 \%, 42.5 \%, 32 \%$ significantly different $(P<0.05)$ towards and $\mathrm{T} 2$ by $63 \%, 57.5 \%$, $42.5 \%, 31.5 \%, 17 \%$. T1 diluent (BTS) produces the highest motility of individual spermatozoa at the cold storing period at the 3rd, 9th, 24th, 48th and 72nd hours. This is because BTS diluent is more suitable in maintaining quality (individual motility, viability, normal shape and membrane integrity) of pig spermatozoa during cold storage.

The results of variance analysis show that the longer the storage time/period the percentage of motility decreases. Membrane damage can cause ATP production to stop and the spermatozoa cannot move. The decrease in the percentage of spermatozoa motility during storage is due to the reduced energy reserves of the spermatozoa to move (Nugroho et al., 2014).

According to the Indonesian National Standard (SNI) No. 8034 in 2014 about pig liquid Semen, preserved pig liquid Semen must show spermatozoa motility at least $40 \%$ and movement of individual spermatozoa with a minimum score of 2 (two). Based on Table 2 above the average percentage of spermatozoa motility during the study of the use of BTS diluent during cold storage at a refrigerator temperature of $2-5^{\circ} \mathrm{C}$ until the 48th hour, it still has motility in the SNI standard so that it can be used for artificial insemination (> 40\%). While the diluent of Tris Aminomethane + egg yolk $20 \%$ the average motility above $40 \%$ only found at the 24th hours after storage treatment.

Pearson`s Chi Square test results with an expected value of the percentage of motility equal to $40 \%$ at the 48th hours the T1 diluent was not significantly different $(P>0.05)$ this shows that the $\mathrm{T} 1$ diluent stored at the temperature of $2-5^{\circ} \mathrm{C}$ can still be used for Al until the 48th hours storage period. Whereas for the 24th hour storage period the T2 diluent is not significantly different $(P>0.05)$ which stored at temperatures of $2-5^{\circ} \mathrm{C}$ can be used for Al until the 24th-hour storage time because the total of motile spermatozoa was not significantly different from the expected value of 40 million spermatozoa $/ \mathrm{ml}$.

The integrity of the plasma membrane is important for maintaining the viability of spermatozoa (Shukla, 2011). Hypo-osmotic Swelling (HOS) Test is a relatively easy method for evaluating the functional integrity of the spermatozoa membrane. Spermatozoa that have 
good integrity are characterized by tails that are circular or bulging, while damaged spermatozoa are marked by a straight tail.

The average and SD values of spermatozoa membrane integrity in this study during storage at the temperature of $2-5^{\circ} \mathrm{C}$ can be seen in Table 3.

Table 3 - Percentage of Integrity of Landrace Pig Spermatozoa Membrane at temperatures of $2-5^{\circ} \mathrm{C}$

\begin{tabular}{ccc}
\hline Hour & Treatment & Spermatozoa Membrane Integrity (\%) \\
\hline \multirow{2}{*}{3} & T1 & $83.58 \pm 1.71$ \\
& T2 & $83.26 \pm 1.71$ \\
\hline \multirow{2}{*}{6} & T1 & $77.68 \pm 2.09^{\mathrm{b}}$ \\
\multirow{2}{*}{9} & T2 & $75.84 \pm 2.09^{\mathrm{a}}$ \\
\hline \multirow{2}{*}{24} & T1 & $73.59 \pm 2.09^{\mathrm{b}}$ \\
& T2 & $66.5 \pm 2.09^{\mathrm{a}}$ \\
\hline \multirow{2}{*}{48} & T1 & $64.61 \pm 2.24^{\mathrm{b}}$ \\
& T2 & $53.85 \pm 2.24^{\mathrm{a}}$ \\
\hline \multirow{2}{*}{72} & T1 & $52.71 \pm 2.35^{\mathrm{b}}$ \\
& T2 & $41.78 \pm 2.35^{\mathrm{a}}$ \\
\hline \multirow{2}{*}{ T1 } & T2 & $42.18 \pm 1.79^{\mathrm{b}}$ \\
\hline
\end{tabular}

Note: 1. T1 (BTS) and T2 (CEP-3 + KT 10\%); 2. Different notations in the same column show significantly different $(P<0.05)$.

The results of the variance analysis showed that the storage period of the 3rd hours the diluent type had no effect $(P>0.05)$ on the membrane integrity of the Landrace pig spermatozoa. While the Duncan Test results show that the percentage of membrane integrity values of spermatozoa at the 6th, 9th, 24th, 4h8t, and 72nd hours shows that treatment T1 with a value of $77.68 \%, 73.59 \%, 64.61 \%, 52.71 \%$, and $42.18 \%$ respectively gave a significant effect $(\mathrm{P}<0.05)$ on T2 with a value of $75.86 \%, 67.73 \%, 57.95 \%, 47.09 \%$ and $33.71 \%$ respectively. These results indicate that at storage period of the $3 \mathrm{rd}$, 6th, 9th, 24th, 48th and 72nd the T1 diluent has a higher percentage value than T2 diluent.

Addition of egg yolk as extracellular cryoprotectant containing lecithin and lipoprotein can also protect the membrane of spermatozoa to prevent cold shock during cold storage (Nugroho et al., 2014).

Data analysis in the table above shows that liquid Semen will experience the decrease in the membrane integrity of spermatozoa if stored for long periods of time either in cold temperatures and room temperature. This is in accordance with the results of the study of Hiwasa et al., (2009) reported that post-thawing spermatozoa membrane integrity of the whale stored at different temperatures and different diluents will also decrease. if the plasma membrane of spermatozoa cells can be maintained its integrity, it will have a good effect on motility, life force and integrity of the spermatozoa acrosome hood.

\section{CONCLUSION AND SUGGESTIONS}

Diluents that has a higher advantage in maintaining the quality of Landrace pig liquid Semen at a temperature of $2-50 \mathrm{C}$ is BTS diluent which has the highest percentage of motility compared to CEP-3 diluent $+10 \%$ egg yolk. From the results of the study show that BTS diluent can be stored for 48 hours with a higher percentage of membrane integrity whereas CEP-3 diluent $+10 \%$ egg yolk can be stored for 24 hours with a minimum percentage of spermatozoa motility of $40 \%$. It is recommended that the use of Pig Landrace Semen for Al purposes using BTS diluent should be stored for 48 hours while the CEP-3 diluent $+10 \%$ egg yolk should be stored for 24 hours.

\section{ACKNOWLEDGMENTS}

We thank you to the management of the Laboratory of the Faculty of Agriculture, the University of Timor for supporting researchers during the research by providing research locations and materials. 


\section{REFERENCES}

1. Aberle ED, Forrest JC, Gerrard DE, Mills EW. 2001. Principles of Meat Science. Ed ke-4. lowa (USA): Kendall/Hunt Publishing Company.

2. Bearden, H.J. and W. Fuquay. 2000. Applied Animal Reproduction 5th Ed. Prentice Hall. UpperSaddle River. New Jersey

3. Gadea, J. 2003. Semen extenders used in the artificial insemination of swine. Spanish J. Of Agric. Research 1:17-27.

4. Garner, D.L. and E.S.E. Hafez, 2008. Spermatozoa and Seminal Plasma, in Reproduction in Farm Animal. 7th eds. 2008. Lippincott \& Williams. Baltimore, Marryland. USA: 96-109.

5. Hiwasa, M., Y. Suzuki and H. Watanabe, 2009.Effects of Semen Extenders and Storage Temperatures on Characteristics of Frozen-Thawed Bryde's (Balaenoptera edeni) Whale Spermatozoa. Journal of Reproduction an Development 55 (6): 599-606.

6. Indriani, T. Susilawati dan S. Wahyuningsih. 2013. Daya Hidup Spermatozoa Sapi Limousin yang Dipreservasi dengan Metode Water Jacket dan Free Water Jacket. Jurnal Veteriner 14 (3): 379-386.

7. Johnson, L.A., K.F. Weitze, P. Fiser and W.M.C.Maxwell. 2000. Storage of boar semen. J Anim Sci 62: 143-172.

8. Kadirvel G, Nasker S, Das A, Hasin D. 2005.Effect of different extenders on preservation of boar semen at $17{ }^{\circ} \mathrm{C}$ [abstrack]. Di dalam: Gadella B.M \& Colenbrander B, editor. Proceedings of the V International Conference on Boar Semen Preservation; 2003 Agt 24-27; Doorwerth, the Netherlands. Theriogenology. 63: 685-692.

9. Kardivel, G., S. kumar, and A. Kumaresan, 2009.Lipid Peroxidation, Mitochhondrial Membran Potentian and DNA Integrity of Spermatozoa in Relation to Intracellular Reactive Oxygen Spesies in Liquid and Frozen. J. Animal reproduction Science. 114: 125-134.

10. Kommisrud E, Paulenz H, Sehested E, Grevle I.S. 2002. Influence of boar and semen parameter on motility and acrosome integrity in liquid boar semen stored for five days. Acta Vet Scand. 43(1):49-55.

11. Nugroho, Y., T. Susilawati dan S. Wahyuningsih. 2014. Kualitas Semen Sapi Limousin Selama Pendinginan Menggunakan Pengencer CEP-2 dengan Penambahan Berbagai Konsentrasi Kuning Telur dan Sari Buah Jambu Biji (Psidium guajava). J. Ternak Tropika 15 (1): 31-42.

12. Robert, V.K. 2006.Semen processing.Extending \& Storage for Artificial Insemination in Swine.Dept.of Animal Science University of Illinois.

13. [SNI] Standar Nasional Indonesia. 2014. SNI 8034:2014 Tentang Semen Cair Babi. Jakarta (ID). Badan Standardisasi Nasional.

14. Sholikah, N., N. Isnaini, A.P.A. Yekti, dan T. Susilawati. 2016. Pengaruh Penggantian Bovine Serum Albumin (BSA) dengan Putih Telur pada CEP-2 terhadap Kualitas Semen Sapi Peranakan Ongole pada Suhu Penyimpanan 3-50C. Jurnal Ilmu-ilmu Peternakan 26(1): 7-15

15. Shukla, M.K. 2011. Applied Veterinary Andrology and Frozen Semen Technology. New India Publishing Agency. India. ISBN: 978-93-80235-64-6.

16. Sumardani NLG., LY. Tuty, PH. Siagian, 2008. Viabilitas Spermatozoa Babi Dalam Pengencer BTS (Beltsville Thawing Solution) yang Dimodifikasi pada Penyimpanan Berbeda.Media Petern. 31: 81-86.

17. Susilawati, T. 2011. Spermatology. Universitas Brawijaya Pres. Malang. ISBN: 978-6028960-04-05

18. Susilawati, T. 2013. Pedoman Inseminasi Buatan Pada Ternak. Universitas Brawijaya Pres. Malang. ISBN: 978-602-203-458-2

19. Zaenuri L.A., Susilawati T., Wahyuningsih S., \& Sumitro S.B. (2014). Preservation Effect of Crude Fig Fruit Filtrate (Ficus carica L) Added In to Tris Egg Yolk Based Extender on Capacitating, Acrosome and Fertility of Half Blood Boer Buck Spermatozoa. IOSR Journal of Agriculture and Veterinary Science, 7(5), 60-68. 